\title{
Effect of Different PCI Practice on the Texture Obtained during Reduction of Iron Oxide Pellets
}

\author{
Ulrika LEIMALM, ${ }^{1)}$ Lena Sundqvist ÖKVIST ${ }^{2)}$ and Bo BJÖRKMAN ${ }^{1)}$ \\ 1) Luleå University of Technology, SE-971 87 Luleå, Sweden. E-mail: ulrika.leimalm@|tu.se, bo.bjorkman@|tu.se \\ 2) MEFOS AB, SE-971 25 Luleå, Sweden. E-mail: lena.sundqvist@mefos.se
}

(Received on July 14, 2000; accepted on October 1, 2008)

\begin{abstract}
In modern blast furnace ironmaking, producers continuously strive to reduce coke consumption by replacing coke with e.g., an increased amount of injected pulverized coal. A change in pulverized coal injection rate $(\mathrm{PCR})$ and injection coal type will influence the in-furnace conditions and thus the reduction of iron oxides. In the present study, the reduction behaviour of olivine pellets and textures formed were investigated in the LKAB Experimental Blast Furnace (EBF) and in laboratory scale. In the EBF, effects of injection of an low-volatile (LV) and an high-volatile (HV) coal type at different PCR while two types of oxygen supply methods were employed were investigated. The choice of injection coal type was conclusive for the $\mathrm{Fe}_{\text {met }}$ texture formed during reduction, extent of $\mathrm{Fe}_{\text {met }}$ carburization and $\mathrm{K}$ distribution in the pellets. The amount of volatile matters in the coal type had a greater effect on the reduction properties than the PCR and oxygen supply method. Laboratory experiments simulating PCR, based on measurements in the EBF, showed that the initial reduction conditions, in terms of temperature level and reduction gas composition, determined the pellet texture up to a reduction degree of at least $60 \%$. The tests carried out in the EBF showed that the pellets were well suited for blast furnace reduction under all the investigated process conditions. The laboratory tests supported this conclusion.
\end{abstract}

KEY WORDS: blast furnace; PCR; injection coal; oxygen supply; pellet reduction; pellet texture; laboratory reduction.

\section{Introduction}

In modern blast furnace ironmaking, producers continuously strive to reduce coke consumption by replacing coke with e.g., an increased amount of injected pulverized coal. Reducing agents are injected mainly for the sake of economy. As the ore-to-coke ratio increases, so does the load on the charged material and the demands on material strength. An increase in the pulverized coal injection rate (PCR) will affect, among other things, the composition of the ascending gases, the position of the in-furnace temperature isotherms and possibly the position of the cohesive zone. All of these parameters are important for the reduction of iron oxides. ${ }^{1)}$

As the PCR increases, the $\mathrm{H}_{2}$ content in the reduction gas will be higher due to an increase in the amount of volatile matters (VM) in the supplied coal. ${ }^{2)}$ It is likely that a highvolatile $(\mathrm{HV})$ coal will generate a higher $\mathrm{H}_{2}$ content than a low-volatile (LV) coal. In-furnace isotherms for $1000^{\circ} \mathrm{C}$, determined with a feed-type vertical probe, move upwards in the shaft with the increase of PCR. ${ }^{3)}$ As a consequence, the cohesive zone will also move upwards, resulting in an increase in high-temperature furnace volume, and thus a possible decrease in the amount of indirect reduction of pellets. Investigations by Peters et al. ${ }^{4)}$ show that the amount of dust in the blast furnace gas increases with a higher PCR. The phenomenon is ascribable to higher gas velocities caused by the increase in ore-to-coke ratio and the more fine-grained nature of burden compared with coke. At the same time, an increase in PCR will generate a higher amount of gas in the blast furnace.

At non-isothermal reduction of low silica hematite pellets in a $\mathrm{CO}-\mathrm{H}_{2}$ atmosphere, Towhidi ${ }^{5,6)}$ showed that the reduction rate was faster at a higher ratio of $\mathrm{H}_{2}$ in $\left(\mathrm{CO}+\mathrm{H}_{2}\right)$ mixture for a constant heating rate and constant initial temperature. Isothermal reduction in a $\mathrm{CO}-\mathrm{CO}_{2}-\mathrm{N}_{2}$ gas mixture over the temperature range $800-1100^{\circ} \mathrm{C}$ has shown that the rate of reduction increases with a higher partial pressure of $\mathrm{CO}$ and $\mathrm{CO} / \mathrm{CO}_{2}$. The higher the temperature the faster was the rate of reduction. Studies have shown that the conditions for the formation of porous iron depend on the gas composition, reaction temperature, oxide stoichiometry and the presence of impurity elements in solid solution in the $\mathrm{FeO} .{ }^{7)}$ During reduction of iron oxides, the initial reduction temperature is of major importance for the pore structure of the reduced iron. ${ }^{8)}$ The pore structure of $\mathrm{Fe}_{\text {met }}$ becomes coarser with increasing temperature. A structure that is formed at a low reduction temperature does not readily coarsen at subsequent temperature rise. A rapid reduction from hematite to wustite without formation of distinct product layers has been reported in pellets of high porosity. The following reduction step of wustite to iron was relatively rapid. The greater the driving force for reduction, the more pronounced was the formation of the product layers. 
In the case of dense sintered hematite pellets, the reduction proceeded topochemically during the formation of product layers. Olsson et al. ${ }^{9)}$ showed that the pore structure of $\mathrm{Fe}_{\text {met }}$ formed during reduction of iron oxides with $\mathrm{H}_{2}$ was a function of the reaction temperature. At a reduction temperature of $900^{\circ} \mathrm{C}$ the pore structure was homogenous. At $500^{\circ} \mathrm{C}$ the pore structure was heterogeneous with large pores, which appeared to follow the initial grain boundaries. Very fine secondary pores were observed through the individual grains. Judging from the photomicrographs by Olsson et al. it can be concluded that the average pore size in the $\mathrm{Fe}_{\text {met }}$ increases with increasing reduction temperature. Wright ${ }^{10)}$ concluded, based on isothermal reduction of pellets in $\mathrm{CO}-\mathrm{H}_{2}$ mixtures, that the structure of metallized pellets was highly temperature dependent. At low reduction temperatures there was a great deal of internal porosity in the individual $\mathrm{Fe}_{\text {met }}$ particles and the interparticle pore sizes were very small. At increased reduction temperature, the voids progressively grow and coalesce with the particle interstices and larger pores are formed.

Laboratory investigations by Geva et al. ${ }^{11)}$ have shown that the presence of impurity elements in solid solution in the iron oxide affect the final iron product morphologies. The presence of $\mathrm{Mg}, \mathrm{Ti}, \mathrm{Si}, \mathrm{Ca}, \mathrm{Na}$ and $\mathrm{K}$ together with $\mathrm{FeO}$ resulted in a decrease in the $\mathrm{CO}$ concentrations necessary to obtain porous iron growth at any reaction temperature relative to reaction with pure wustite. $\mathrm{P}$ had a marginal effect on the porous/dense iron transition and Al restricted the range of gas compositions over which porous iron could be obtained. In $\mathrm{H}_{2} / \mathrm{H}_{2} \mathrm{O}$ mixtures, the presence of Ti, $\mathrm{Mg}, \mathrm{P}$, $\mathrm{Si}, \mathrm{Ca}, \mathrm{K}$ and $\mathrm{Na}$ favoured porous iron formation. Additions of $\mathrm{Al}$ made the formation of a porous iron layer difficult. The effects of impurities were additive. $\mathrm{Na}$ and $\mathrm{K}$ are present in the blast furnace and are generally undesirable, but can on the other hand play a significant role in improving the reducibility of the burden. $\mathrm{K}$ has been reported to function as a catalyst for the reduction of iron oxide. ${ }^{12}$ ) Since the solubility of $\mathrm{K}$ in bulks of iron oxides has been reported not to exceed $0.1 \mathrm{wt} \%$, much of the $\mathrm{K}$ is expected to exist on the surface of iron oxides. ${ }^{13)}$

In the blast furnace, the accumulated amounts of $\mathrm{K}, \mathrm{Na}$ and $\mathrm{F}$ have been shown to be greater in the lower shaft than in the upper shaft. ${ }^{12)}$ The gas stream is the transportation medium for these elements. Alkalis are transported from gas to burden in the lower temperature zone and from burden to gas in elevated temperature zones. Laboratory experiments carried out by Lectard et al. ${ }^{14)}$ showed that an alkaline atmosphere generated with a coke impregnated with potassium carbonate would, especially at low temperatures, have a catalytic effect on the reduction of sinter.

Pellet reduction properties are affected by the reduction gas composition and temperature. As a consequence, differences in reduction behaviour and pellet textures arise. In the blast furnace, a number of factors influence the conditions for pellet reduction. In the present study the effects of PCR, injection coal type and method for oxygen addition on the pellet reduction behaviour were investigated. Tests were carried out in the LKAB Experimental Blast Furnace (EBF) and in laboratory scale. Possible connections to dust forming are discussed. Results from the laboratory studies were previously presented. ${ }^{15)}$

\section{Experimental}

\subsection{Materials}

Commercial pellets produced by LKAB were used in the investigations performed. Material sampling of pellets for the laboratory investigations was carried out at an LKAB pelletizing plant. The chemical composition of the olivine pellets is presented in Table 1. Two different coal types were used in the EBF trial; an LV coal containing 19.6\% $\mathrm{VM}$ and an HV coal containing 38.0\% VM. Coke in the $15-30 \mathrm{~mm}$ fraction and BOF slag in the $9-15 \mathrm{~mm}$ fraction was supplied by SSAB. To obtain a desired slag basicity and slag volume, quartzite, BOF slag and limestone were used as slag formers.

\subsection{The EBF}

The EBF situated at MEFOS has a working volume of $8.2 \mathrm{~m}^{3}$ and a diameter at tuyere level of $1.2 \mathrm{~m}$ and is equipped with a system for injection of reduction agents. The pulverized coal injection (PCI) system is an oxy coal system and the oxygen added to the lance can be replaced by air if desired. The height from tuyere level to stock line is $6 \mathrm{~m}$ and there are three tuyeres separated by $120^{\circ}$. During an EBF trial, the PCR, coal type and methods for oxygen supply were changed for the 6 test periods presented in Table 2. In the tables and figures, operation with oxygen added to the lance is termed Oxy Coal and operation with air addition to the lance termed Air Coal. The behaviour of the pellets related to the pre-set process conditions was investigated and evaluated.

During operation, in-burden probes, employed for each parameter setting, were used for sampling of the burden and for measurement of the horizontal gas- and temperature profiles. The material taken out with the horizontal probes

Table 1. Chemical composition of the MPBO in percent. ${ }^{16)}$

\begin{tabular}{c|ccccccc}
\hline Pellet & $\mathrm{Fe}$ & $\mathrm{FeO}$ & $\mathrm{CaO}$ & $\mathrm{SiO}_{2}$ & $\mathrm{MgO}$ & $\mathrm{Al}_{2} \mathrm{O}_{3}$ & $\mathrm{CaO} / \mathrm{SiO}_{2}$ \\
\hline MPBO & 66.8 & 0.5 & 0.35 & 1.7 & 1.5 & 0.32 & 0.21 \\
\hline
\end{tabular}

Table 2. Overview of the pre-set process conditions during the EBF trial.

\begin{tabular}{c|ccc}
\hline \multirow{2}{*}{ Test Period } & Coal type & Process parameters & Method for oxygen supply \\
\hline 1 & LV & 152 & Oxy Coal \\
2 & LV & 146 & Air Coal \\
3 & LV & 79 & Oxy Coal \\
4 & HV & 94 & Oxy Coal \\
5 & HV & 152 & Oxy Coal \\
6 & HV & 143 & Air Coal \\
\hline
\end{tabular}


was divided in sub-samples. 3-4 sub-samples were generated for each probe. 5 sub-samples are during ideal conditions generated from the upper shaft probe and 6 from the lower. Estimation of the positions of the in-furnace temperature isotherms was done by allowing a thermocouple to descend with the burden.

\subsection{Laboratory Reduction}

\subsubsection{The Laboratory Reduction Furnace}

The experimental apparatus used for reduction tests is shown in Fig. 1. The furnace is a vertical steel tube-type furnace with an inner diameter of about $60 \mathrm{~mm}$ and is heated electrically by U-shaped Super-Kanthal elements with a constant temperature zone of about $80 \mathrm{~mm}$ in height. Input gas composition and temperature are controlled by a computer which also is used to store data with a pre-set frequency chosen for the parameters time, temperature and input gas composition. The gas supply system is equipped with digital Multi-Bus Flow-Bus regulators for input gas flows of $\mathrm{CO}, \mathrm{H}_{2}, \mathrm{CO}_{2}$ and $\mathrm{N}_{2}$. The gas is introduced in the bottom of the tube and heated in a bed of $\mathrm{Al}_{2} \mathrm{O}_{3}$ balls. $\mathrm{A}$ thermocouple for temperature measurement and control is introduced from the bottom of the tube and situated approximately $20 \mathrm{~mm}$ below the sample, which is suspended in the balance with metal wires. The sample material was placed in a basket. A water-cooled top for cooling of the sample after test completion is situated on top of the steel tube. At the test starting temperature, a nitrogen flow at $12 \mathrm{~L} / \mathrm{min}$ was introduced. The temperature and gas flow were held at constant values for a few minutes before the sample was introduced into the furnace. Each sample consisted of dry pellets with an initial weight of 80 to $83 \mathrm{~g}$. As soon as the sample had been introduced into the constant temperature zone, the test was started and the temperature program started at the same time as the gas composition was changed into a reducing atmosphere. After the test, which could be interrupted at any point, the gas was changed to pure $\mathrm{N}_{2}$ and the sample was transferred into the cooling top. Total gas flow was maintained at $12 \mathrm{~L} / \mathrm{min}$ during the entire test.

\subsubsection{Heating Rate and Gas Composition Profiles}

The laboratory test programs were based on measurements in the EBF during test periods 1 and 3. A fast heating rate was estimated to simulate a centre profile and a slow heating rate was estimated to simulate an intermediate/wall profile. The heating rate profiles were estimated from vertical temperature measurements, average burden decent rates, horizontal temperature profiles at the position of the shaft probes and $\mathrm{CO} / \mathrm{CO}_{2}$ ratios at the position of the lower shaft probe for temperature estimation from an oxygen potential diagram. Vertical temperature measurements in the EBF showed fast temperature increases up to well above $1000^{\circ} \mathrm{C}$ followed by slower temperature increases, which were assumed to correspond to the thermal reserve zones. The gas composition at different temperatures was based on the top gas compositions and the in-burden gas analysis made with the upper and lower shaft probes during test periods 1 and 3. The gas compositions used together with the fast heating rates were estimated from the centre gas composition in the EBF. For the slow heating rates, the gas compositions at an

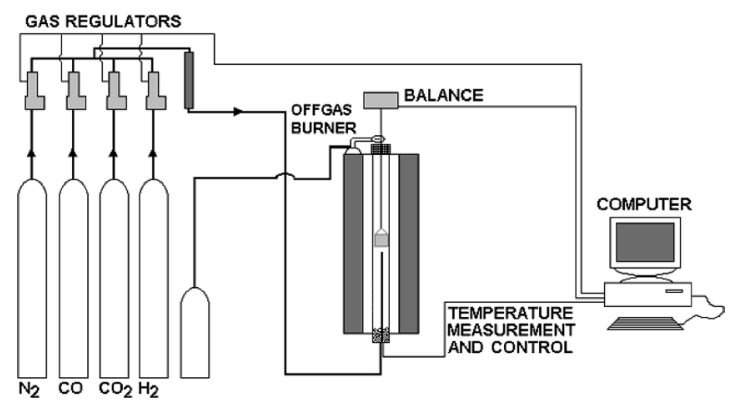

Fig. 1. Schematic view of the experimental apparatus used for the laboratory reduction tests.

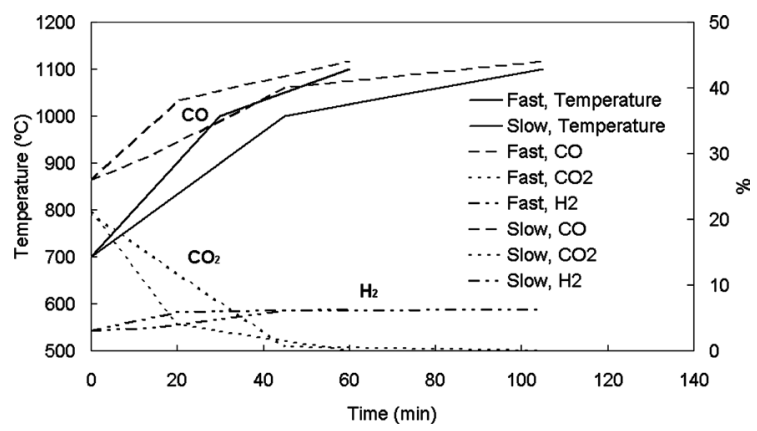

Fig. 2. Heating rate and gas composition profiles for experiments simulating high PCR. Heating rate and gas profiles estimated from measurements in the EBF.

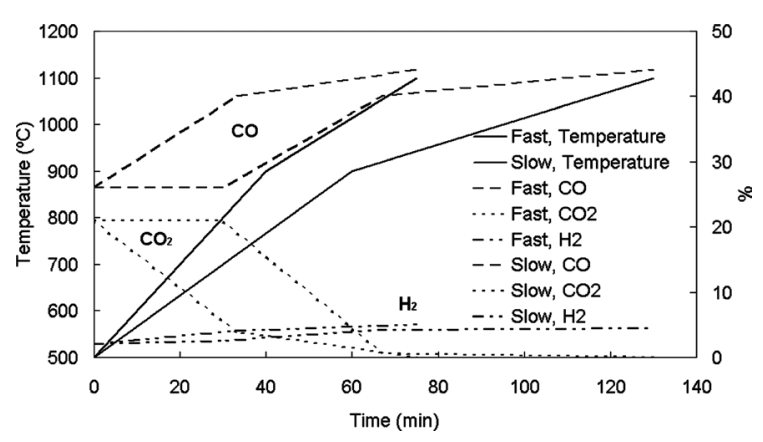

Fig. 3. Heating rate and gas composition profiles for experiments simulating low PCR. Heating rate and gas profiles estimated from measurements in the EBF.

intermediate position in the EBF were the basis of the reduction gas composition. Figures $\mathbf{2}$ and $\mathbf{3}$ show the gas and temperature profiles used in laboratory reduction tests. $\mathrm{N}_{2}$ was filled up to maintain a total gas flow of $12 \mathrm{~L} / \mathrm{min}$ during the tests. One set of experiments was interrupted at a reduction degree of approximately $40 \%$ and one set was interrupted at a furnace temperature of $1100^{\circ} \mathrm{C}$. An overview of the experiments performed is given in Table 3 .

\subsection{Evaluation of Pellet Properties}

\subsubsection{Pellet Textures}

Pellet textures were investigated by light optical microscopy (LOM) and by scanning electron microscopy (SEM) equipped with Energy Dispersive X-ray Analysis (EDS). Prior to observation, pellets were cold-mounted in epoxy resin. In order to observe the largest pellet cross section, the mounts were cut at the maximum pellet diameters. The surface of the section was polished. Prior to SEM investigation, the cross sections of the mounted pellet sam- 
Table 3. Schematic overview of blast furnace simulating experiments.

\begin{tabular}{|c|c|c|c|c|c|c|c|c|}
\hline \multirow{3}{*}{ Test } & \multicolumn{2}{|c|}{ PCR } & \multicolumn{4}{|c|}{ Heating Rate } & \multicolumn{2}{|c|}{ Test End } \\
\hline & \multirow{2}{*}{ High } & \multirow{2}{*}{ Low } & \multicolumn{2}{|c|}{ Fast } & \multicolumn{2}{|c|}{ Slow } & \multirow{2}{*}{$\begin{array}{c}\text { Red. Degree } \\
40 \%\end{array}$} & \multirow{2}{*}{$\begin{array}{l}\text { Temp. } \\
1100^{\circ} \mathrm{C}\end{array}$} \\
\hline & & & High PCR & Low PCR & High PCR & Low PCR & & \\
\hline I & $\mathrm{X}$ & & $\mathrm{X}$ & & & & $\mathrm{X}$ & \\
\hline II & $\mathrm{X}$ & & $\mathrm{X}$ & & & & & $\mathrm{X}$ \\
\hline III & $\mathrm{X}$ & & & & $\mathrm{X}$ & & $\mathrm{X}$ & \\
\hline IV & $\mathrm{X}$ & & & & $\mathrm{X}$ & & & $\mathrm{X}$ \\
\hline $\mathrm{V}$ & & $\mathrm{X}$ & & $\mathrm{X}$ & & & $\mathrm{X}$ & \\
\hline VI & & $\mathrm{X}$ & & $\mathrm{X}$ & & & & $\mathrm{X}$ \\
\hline VII & & $\mathrm{X}$ & & & & $\mathrm{X}$ & $\mathrm{X}$ & \\
\hline VIII & & $X$ & & & & $\mathrm{X}$ & & $X$ \\
\hline
\end{tabular}

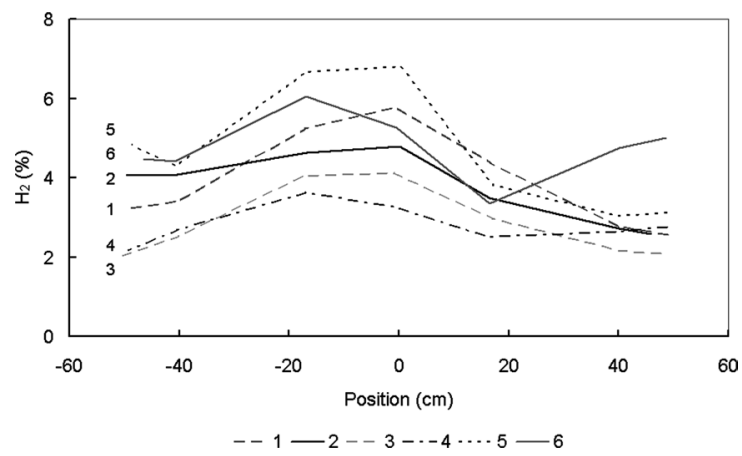

Fig. 4. $\mathrm{H}_{2}$ at the position of the upper shaft probe in the EBF during test periods 1-6 with different PCR, injection coal types and methods for oxygen supply.

ples were coated with a thin layer of gold.

\subsubsection{Identification of Trace Elements in Pellets}

In order to identify trace elements in the pellet periphery and core, pellets from sub-sample 3 taken out with the lower shaft probe were rotated in an I-drum at 600 revolutions for $30 \mathrm{~min}$. After I-drum treatment, pellet fragments in the size range $212 \mu \mathrm{m}-1.5 \mathrm{~mm}$ and $>10 \mathrm{~mm}$ were separately ground in a ring mill and X-Ray diffraction was carried out on the ground materials. A Copper $\mathrm{K} \alpha$ radiation $(40 \mathrm{kV}, 40 \mathrm{~mA})$ was used as the X-ray source. The samples were scanned over an angular range of $\sin 2 \theta 10-90^{\circ}$ by using a step size of $0.020^{\circ}$ and over $\sin 2 \theta 35-55^{\circ}$ with a step size of $0.020^{\circ}$ and a step time of $6 \mathrm{~s}$ at each step. For the $>10 \mathrm{~mm}$ fraction, XRD and chemical analyses were carried out after operation at the low PCR, periods 3 and 4 .

\section{Results}

\section{1. $\mathrm{EBF}$}

The horizontal $\mathrm{H}_{2}$ profile at the position of the upper shaft probe during the 6 test periods is shown in Fig. 4. The $\mathrm{H}_{2}$ content in the reduction gases was observed to increase with increasing PCR. Addition of $\mathrm{O}_{2}$ to the lance as well as operation using the $\mathrm{HV}$ coal resulted also in a higher $\mathrm{H}_{2}$ amount. At the position of the lower shaft probe, the $\mathrm{H}_{2}$ content in the reduction gas reached a higher level than at the position of the upper shaft probe. The $\mathrm{CO}$ content in the reduction gas was observed to reach a higher level at the position of the upper shaft probe during operation using the LV coal compared to operation using the HV coal, see Fig. 5.

\subsubsection{Pellet}

Figures 6 and 7 show typical textures of pellet cores and peripheries obtained in pellets taken out with the upper shaft probe during test periods $1-3$ respectively 4-6. Mag-

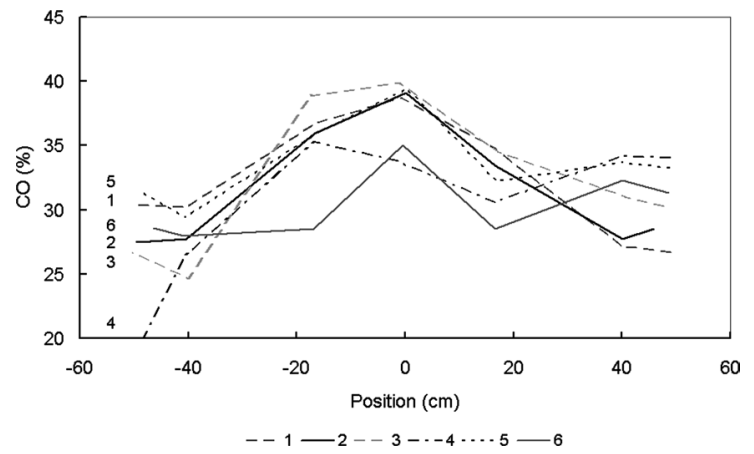

Fig. 5. $\mathrm{CO}$ at the position of the upper shaft probe in the EBF during test periods $1-6$ with different PCR, injection coal types and methods for oxygen supply.

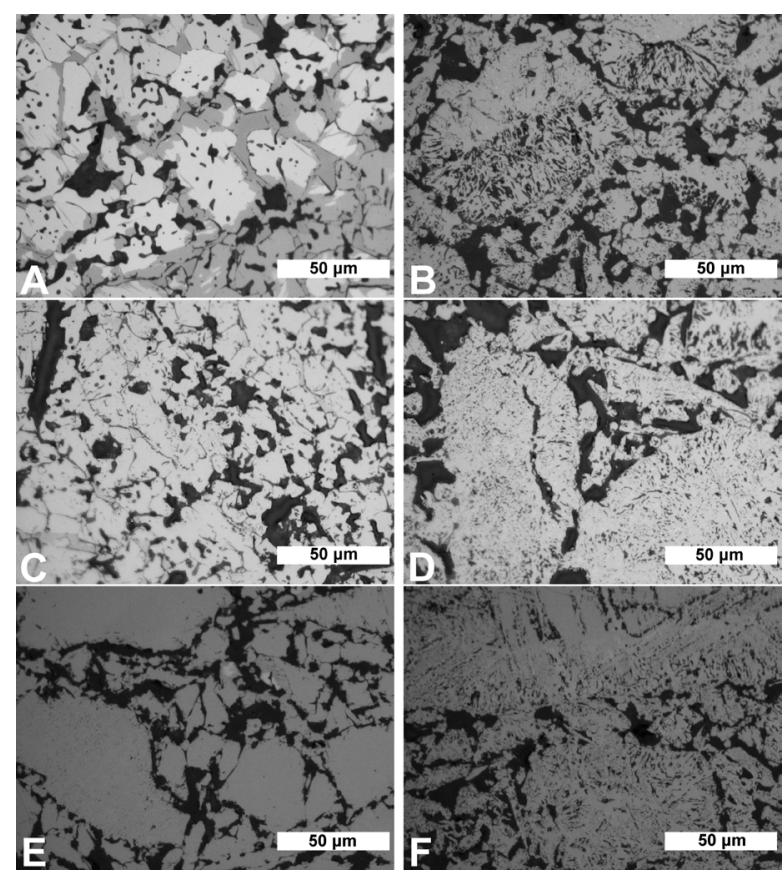

Fig. 6. Typical textures, observed in light optical microscope, of pellets taken out with the upper shaft probe in the EBF during LV-coal operation. A, C and $\mathrm{E}=$ pellet core, $\mathrm{B}, \mathrm{D}$ and $\mathrm{F}=$ pellet periphery. Test period $1, \mathrm{~A}$ and $\mathrm{B}$, test period 2, $\mathrm{C}$ and $\mathrm{D}$ and test period 3, E and F. Hematite= light grey, magnetite $=$ smooth grey, wustite $=$ broken grey, $\mathrm{Fe}_{\text {met }}=$ white, pores $=$ black.

netite dominated the cores of pellets taken out with the upper shaft probe during injection of the LV coal in test periods $1-3$. Some hematite and wustite were also observed in the pellet cores. The pellet peripheries were made up of wustite. Wustite and magnetite dominated in the pellet cores in pellets taken out with the upper shaft probe during injection of the HV coal in test periods 4-6. A few areas of $\mathrm{Fe}_{\text {met }}$ observed in the pellet core increased in size and num- 


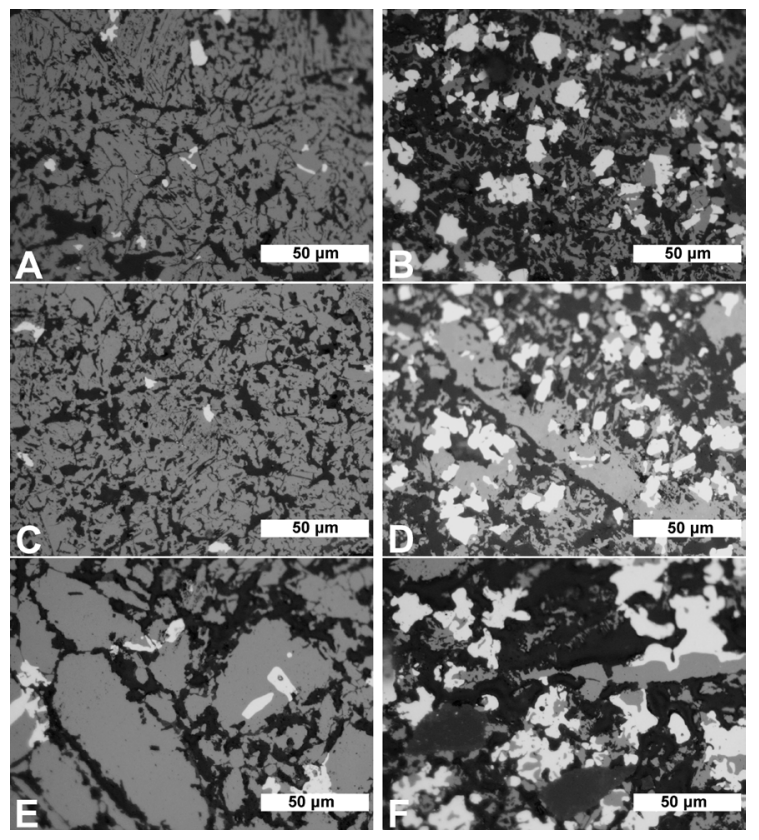

Fig. 7. Typical textures, observed in light optical microscope, of pellets taken out with the upper shaft probe in the EBF during HV-coal operation. A, C and $\mathrm{E}=$ pellet core, $\mathrm{B}, \mathrm{D}$ and $\mathrm{F}=$ pellet periphery. Test period $4, \mathrm{~A}$ and $\mathrm{B}$, test pe$\operatorname{riod} 5, \mathrm{C}$ and $\mathrm{D}$ and test period $6, \mathrm{E}$ and $\mathrm{F}$. Hematite $=$ light grey, magnetite $=$ smooth grey, wustite $=$ broken grey, $\mathrm{Fe}_{\text {met }}=$ white, pores $=$ black .

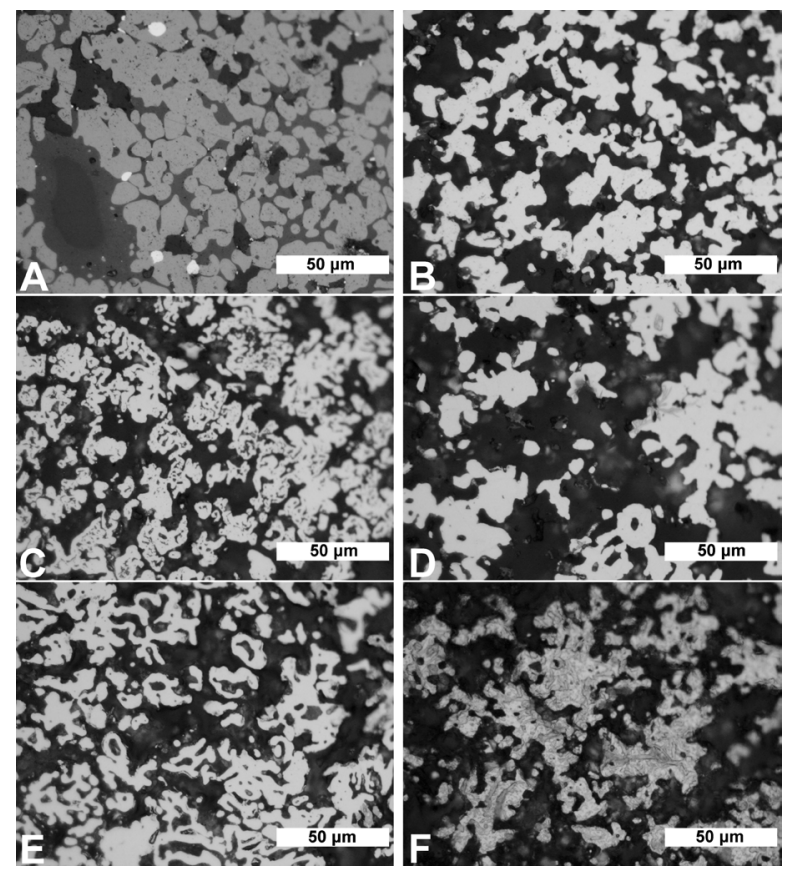

Fig. 8. Typical textures, observed in light optical microscope, of pellets taken out with the lower shaft probe in the EBF during $\mathrm{LV}$-coal operation. $\mathrm{A}, \mathrm{C}$ and $\mathrm{E}=$ pellet core, $\mathrm{B}, \mathrm{D}$ and $\mathrm{F}=$ pellet periphery. Test period $1, \mathrm{~A}$ and $\mathrm{B}$, test period 2, $\mathrm{C}$ and $\mathrm{D}$ and test period 3, $\mathrm{E}$ and $\mathrm{F}$. Wustite $=$ grey, $\mathrm{Fe}_{\text {met }}=$ white (lightest), pores $=$ black .

ber towards the periphery. Wustite and $\mathrm{Fe}_{\text {met }}$ dominated the periphery. The transition between the texture in the pellet core and periphery was blurry and any distinct product layers were not formed.

In pellets taken out with the lower shaft probe, $\mathrm{Fe}_{\text {met }}$

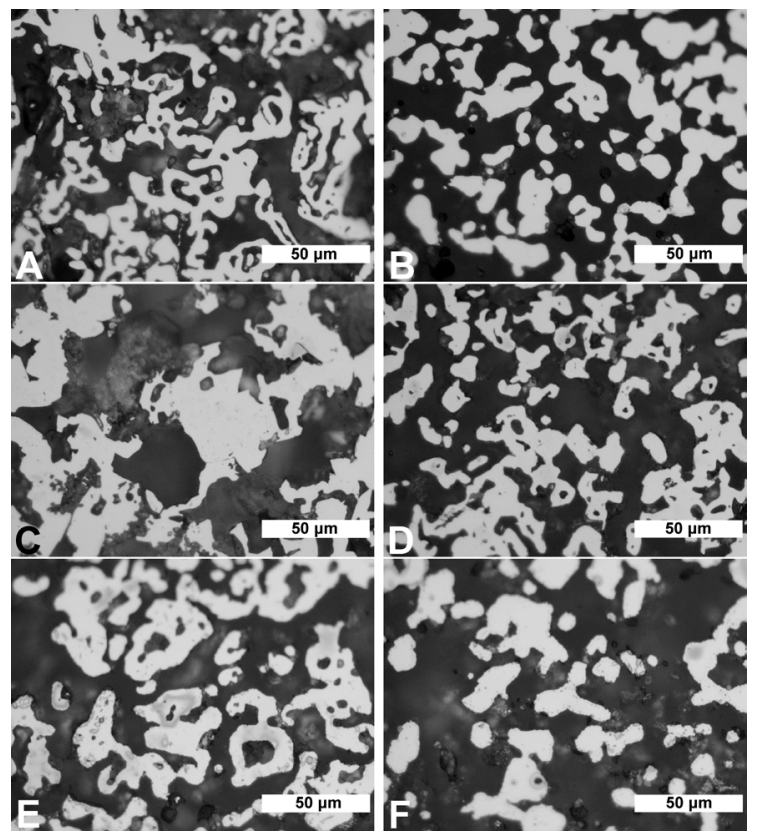

Fig. 9. Typical textures, observed in light optical microscope, of pellets taken out with the lower shaft probe in the EBF during HV-coal operation. A, C and $\mathrm{E}=$ pellet core, $\mathrm{B}, \mathrm{D}$ and $\mathrm{F}=$ pellet periphery. Test period $4, \mathrm{~A}$ and $\mathrm{B}$, test period 5, $\mathrm{C}$ and $\mathrm{D}$ and test period $6, \mathrm{E}$ and $\mathrm{F}$. Wustite $=$ grey, $\mathrm{Fe}_{\text {met }}=$ white (lightest), pores $=$ black.

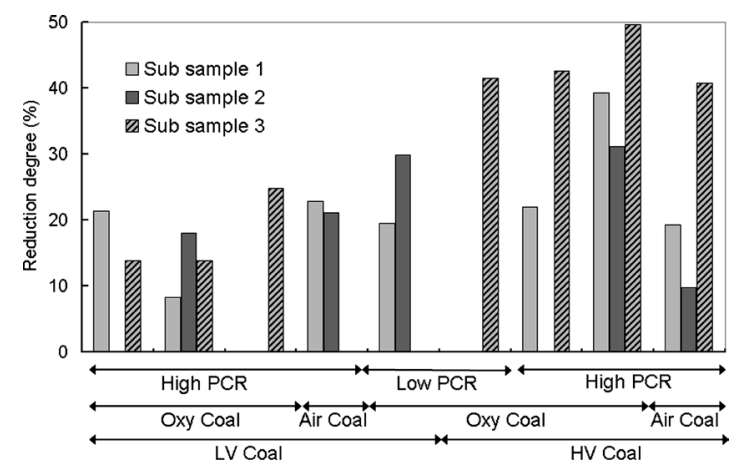

Fig. 10. Pellet reduction degrees in sub-samples 1-3 taken out with the upper shaft probe in the EBF during tests with different PCR, injection coal type and method for oxygen supply.

dominated the texture, see Figs. 8 and 9. Injection of the HV coal type increased the pore size in the periphery when the other test parameters were held constant; a phenomenon noted in comparison of test periods 1 with 5,2 with 6 , and 3 with 4 . Comparing the pellet cores, the size of the continuous $\mathrm{Fe}_{\text {met }}$ areas increased during injection of the HV coal compared to injection of the LV coal at high PCR and independent of oxygen supply method. In the pellet core from period 1, softened wustite dominated.

At the position of the upper shaft probe the highest reduction degrees were attained during injection of the HV coal, see Fig. 10. No correlation between the pellet reduction degree and pre-set process conditions was observed in sub-samples taken out with the lower shaft probe.

Chemical analysis of the pellet fragments in the size range $212 \mu \mathrm{m}-1.5 \mathrm{~mm}$ showed an increased carbon content after operation with injection of the HV coal type, see Fig. 11. Increased contents of $\mathrm{K}$ and $\mathrm{Ca}$ were also observed. Air 


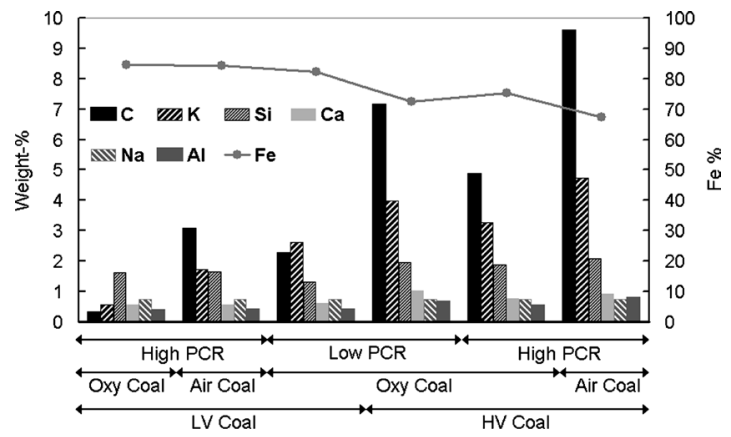

Fig. 11. Element distributions in the fraction $212 \mu \mathrm{m}-1.5 \mathrm{~mm}$ after I-drum treatment of pellets from sub-sample 3 taken out with the lower shaft probe during operation in the EBF at different PCR, injection coal type and methods for oxygen supply.

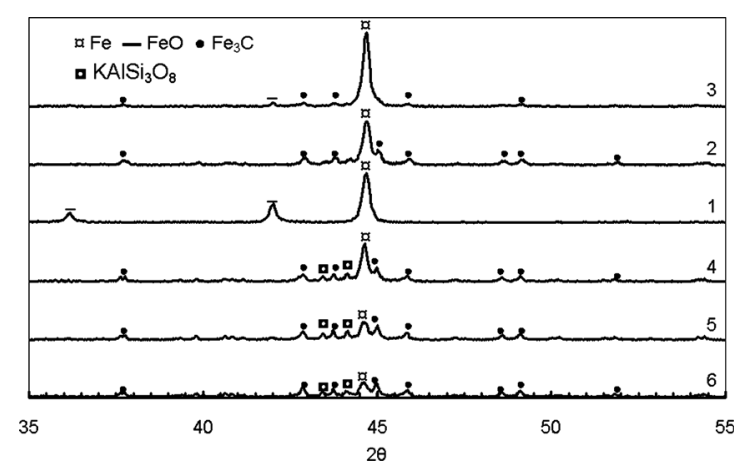

Fig. 12. XRD pattern of ground material after I-drum treatment of pellets from sub-sample 3 taken out with the lower shaft probe during operation in the EBF during test period 1-6.

Table 4. Compounds identified by XRD investigations in the fraction $212 \mu \mathrm{m}-1.5 \mathrm{~mm}$ after I-drum treatment of pellets from sub-sample 3 taken out with the lower shaft probe during operation in the EBF during test periods $1-6$.

\begin{tabular}{c|ccc}
\hline Test period & \multicolumn{3}{c}{ Compound } \\
\hline 1 & $\mathrm{Fe}$ & $\mathrm{FeO}$ & $\mathrm{Fe}_{3} \mathrm{C}$ \\
2 & $\mathrm{X}$ & $\mathrm{X}$ & $\mathrm{X}$ \\
3 & $\mathrm{X}$ & $\mathrm{X}$ & $\mathrm{X}$ \\
4 & $\mathrm{X}$ & & $\mathrm{X}$ \\
5 & $\mathrm{X}$ & & $\mathrm{X}$ \\
6 & $\mathrm{X}$ & $\mathrm{X}$ \\
\hline
\end{tabular}

supply to the lance generated a higher carbon content compared to operation with oxygen addition to the blast air. In the XRD analysis, see Fig. 12, $\mathrm{Fe}_{3} \mathrm{C}$ was observed in samples from test periods 2-6. Table 4 summarizes the compounds identified in the XRD analysis.

For the low PCR, the chemical analysis of the $>10 \mathrm{~mm}$ pellet fragments showed an increased amount of carbon after operation with injection of the $\mathrm{HV}$ coal type. $\mathrm{Fe}_{3} \mathrm{C}$ was observed after operation with injection of the HV coal type and $\mathrm{FeO}$ was observed after injection of the LV coal type. The pellet fragments were mainly made up of $\mathrm{Fe}_{\text {met }}$.

\subsubsection{Distribution of Slag and Trace Elements}

Slag areas were found next to or enclosed in the $\mathrm{Fe}_{\text {met }}$ areas in the entire cross section in pellets taken out with the lower shaft probe during test periods $1-6$. The size and distribution of the slag areas and areas with increased $\mathrm{K}$ content varies between the test periods. Sometimes, the pellet periphery was covered by a layer consisting of mainly $\mathrm{Mg}$, $\mathrm{Si}, \mathrm{K}, \mathrm{Ca}$ and Al. EDS mapping of pellet core and periphery in probe samples of pellets taken out during operation with the LV and HV coal type, test periods 2 and 5, are for Fe and K presented in Figs. 13 and 14.

$\mathrm{K}$ was observed in pellets taken out with the lower shaft probe, independent of pre-set process conditions. Areas of increased $\mathrm{K}$ content in the core of the pellets were found to be next to or surrounded by $\mathrm{Fe}_{\text {met }}$. In pellets taken out during injection of the LV coal type, $\mathrm{K}$ was located next to $\mathrm{Fe}_{\text {met }}$, while $\mathrm{Fe}_{\text {met }}$ surrounded $\mathrm{K}$ after injection of the $\mathrm{HV}$ coal type. In the pellet periphery, $\mathrm{K}$ was found between $\mathrm{Fe}_{\text {met }}$ as well as in the surface cover of pellets, independent of the pre-set process conditions. $\mathrm{K}$ formed compounds with $\mathrm{Si}, \mathrm{Al}$ and $\mathrm{Mg}$. The coexistence of $\mathrm{K}$ and the slag elements was more frequent in the pellet periphery, and especially in the surface cover, compared to the core of the pel-

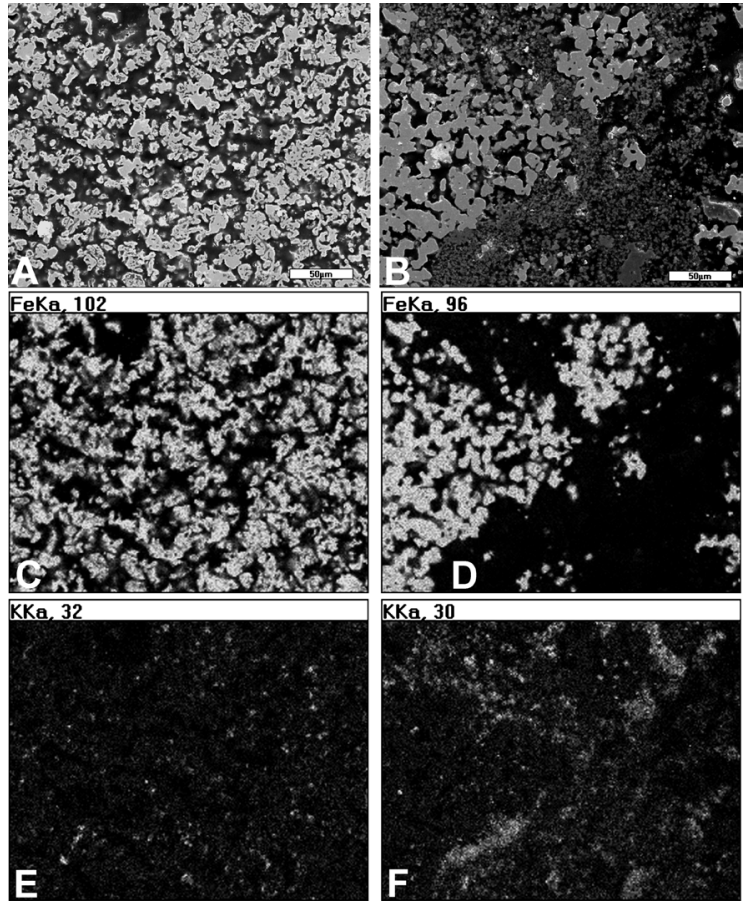

Fig. 13. EDS mapping for $\mathrm{Fe}$ and $\mathrm{K}$ of core (A, $\mathrm{C}$ and $\mathrm{E})$ and periphery/outer edge (B, D and $\mathrm{F}$ ) of pellet taken out with the lower shaft probe during operation with the LV coal type in test period 2 .

lets. $\mathrm{Ca}-\mathrm{Si}$ slag was observed in the pellet cores and coexistence of the elements was observed in the pellet periphery as well as in the surface cover. $\mathrm{Mg}$ and $\mathrm{Si}$ were more frequently found in the same area in the pellet core and surface cover compared to the pellet cores. Al was mainly observed in the surface cover.

In the area between the pellet core and periphery $\mathrm{K}$ was usually observed together with $\mathrm{Si}$ and $\mathrm{Mg}$. The tendency for 


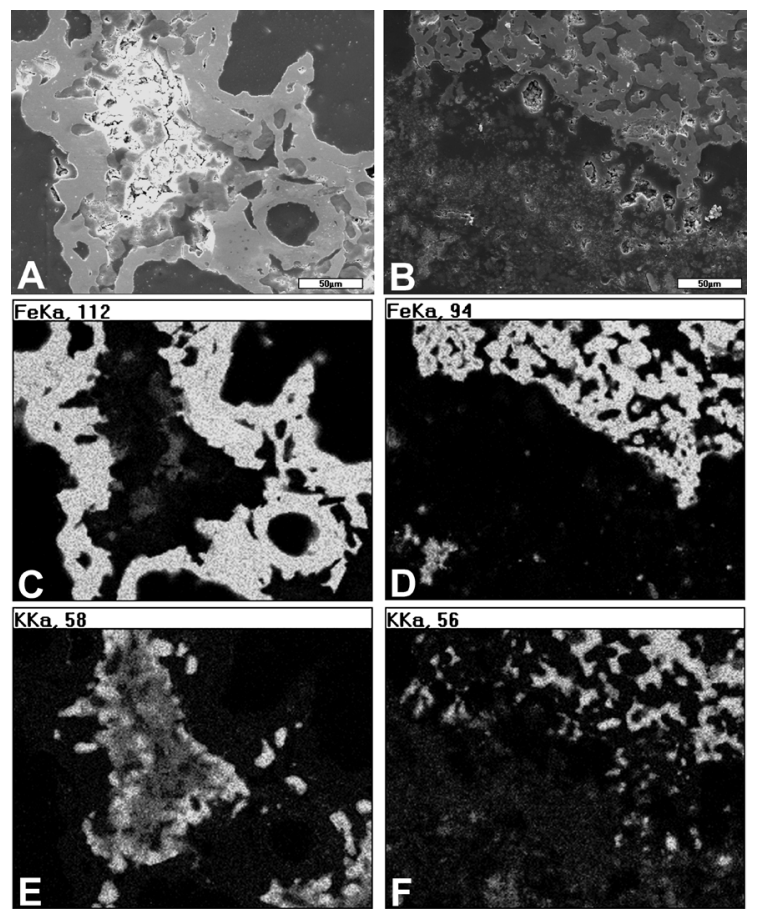

Fig. 14. EDS mapping for $\mathrm{Fe}$ and $\mathrm{K}$ of core $(\mathrm{A}, \mathrm{C}$ and $\mathrm{E})$ and periphery/outer edge (B, D and F) of pellet taken out with the lower shaft probe during operation with the HV coal type in test period 5 .

liquid formation was more pronounced in pellets taken out during injection of the HV coal type, there smooth slag areas was formed compared to the diffuse slag areas during LV coal operation.

\subsection{Laboratory Reduction}

\subsubsection{Reduction Profiles}

Figure 15 shows the reduction profiles for tests I-VIII. For experiments simulating the same level of PCR, at the test end temperature of $1100^{\circ} \mathrm{C}$, a higher reduction degree was attained for the slow heating rates when tests IV and II and tests VIII and VI were compared. After reduction simulating the fast heating rate profiles, tests II and VI, approximately equal reduction degrees were attained independent of simulated PCR. A higher reduction degree was attained for the slow heating rates at the end of test IV, simulating high PCR, compared to test VIII, simulating low PCR. In tests I, III, V and VII, the reduction was interrupted at a reduction degree of approximately $40 \%$.

\subsubsection{Pellet Textures}

Significant differences in the iron oxide textures were observed in the pellet cores when pellets from the reduction experiments simulating the high and low PCR were compared. A grain texture was observed in the pellet core of samples after experiments simulating the low PCR, tests V-VIII, an observation that was not discernible after experiments simulating the high PCR, tests I-IV. Typical pellet textures at a reduction degree of $40 \%$ after tests simulating the low and high PCR with fast heating rate are presented in Fig. 16. Together with the areas of $\mathrm{Fe}_{\text {met }}$ in the pellet periphery, a few areas of iron oxide were present after fulllength tests simulating the high PCR. After full-length tests simulating the low PCR the corresponding areas in the pel-

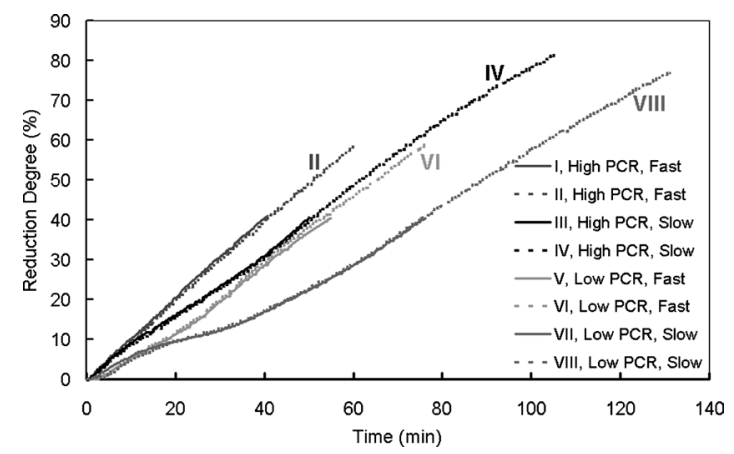

Fig. 15. Reduction profiles for laboratory tests I-VIII. Test II, IV, VI and VIII interrupted at the test end temperature of $1100^{\circ} \mathrm{C}$ and tests I, III, V and VII at an attained reduction degree of approximately $40 \%$.

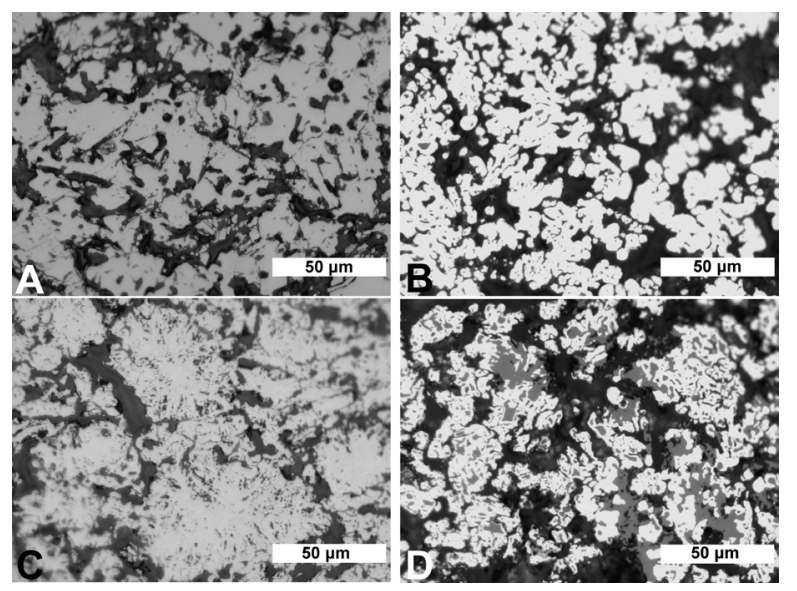

Fig. 16. Pellet textures observed in light optical microscope after reduction tests $\mathrm{I}(\mathrm{A}$ and $\mathrm{B})$ and $\mathrm{V}(\mathrm{C}$ and $\mathrm{D})$. Pellet core ( $A$ and $C$ ) and pellet periphery (B and $D$ ). Iron oxides $=$ grey, $\mathrm{Fe}_{\text {met }}=$ white, pores $=$ black

let periphery showed noticeable areas of iron oxide surrounded by $\mathrm{Fe}_{\text {met }}$ within the texture dominated by $\mathrm{Fe}_{\text {met }}$. A few areas of $\mathrm{Fe}_{\text {met }}$ were observed in the pellet core from test samples interrupted at the test end temperature of $1100^{\circ} \mathrm{C}$. $\mathrm{Fe}_{\text {met }}$ was not observed in the core of pellets reduced to a reduction degree of approximately $40 \%$. No significant differences in the $\mathrm{Fe}_{\text {met }}$ texture of the pellet periphery, independent of final reduction degree, could be observed between pellets reduced according to similar reduction profile. The extension between the pellet core, mainly made up of iron oxide, and the pellet periphery dominated by $\mathrm{Fe}_{\text {met }}$ varied, however, in accordance with the reduction degrees attained. A summary of the observations is presented in Table 5.

\section{Discussion}

\subsection{Reduction}

\subsection{1. $\mathrm{EBF}$}

Changes in the reduction potential of the ascending gas during the EBF tests were mostly a consequence of the differences in $\mathrm{H}_{2}$ content attained during the pre-set test periods. A higher PCR, comparing test periods 1 with 3 and 4 with 5 , increased the $\mathrm{H}_{2}$ content of the ascending gas. Corresponding results were obtained after switching from operation with injection of $\mathrm{LV}$ coal to $\mathrm{HV}$ coal at a high PCR. 
Table 5. Summary of pellet textures and reduction properties attained after laboratory experiments simulating PCR.

\begin{tabular}{|c|c|c|c|c|c|c|c|c|}
\hline \multirow{2}{*}{ Test } & \multicolumn{3}{|c|}{ Pellet Core } & \multicolumn{3}{|c|}{ Pellet Periphery } & \multicolumn{2}{|c|}{$\begin{array}{l}\text { Reduction properties at } \\
1100^{\circ} \mathrm{C}\end{array}$} \\
\hline & Iron oxide & $\mathrm{Fe}_{\text {met }}$ & Grain Texture & Iron oxide & $\begin{array}{r}\mathrm{Fe}_{\mathrm{n}} \\
\text { Dispersed }\end{array}$ & Dense & $\begin{array}{c}\text { Red. Degree } \\
(\%)\end{array}$ & $\begin{array}{l}\text { Red. Tim } \\
\text { (min) }\end{array}$ \\
\hline I & $\mathrm{X}$ & & & $\mathrm{S}$ & $\mathrm{X}$ & & & \\
\hline II & $\mathrm{X}$ & $\mathrm{X}$ & & $\mathrm{F}$ & $\mathrm{X}$ & & 58 & 60 \\
\hline III & $\mathrm{X}$ & & & $\mathrm{S}$ & $\mathrm{X}$ & & & \\
\hline IV & $\mathrm{X}$ & $\mathrm{X}$ & & $\mathrm{F}$ & $\mathrm{X}$ & & 81 & 105 \\
\hline $\mathrm{V}$ & $\mathrm{X}$ & & $\mathrm{X}$ & C & & $\mathrm{X}$ & & \\
\hline VI & $\mathrm{X}$ & X & $\mathrm{X}$ & $\mathrm{S}$ & & $\mathrm{X}$ & 59 & 76 \\
\hline VII & $\mathrm{X}$ & & $\mathrm{X}$ & $\mathrm{C}$ & & $\mathrm{X}$ & & \\
\hline VIII & $\mathrm{X}$ & $\mathrm{X}$ & $\mathrm{X}$ & $\mathrm{S}$ & & $\mathrm{X}$ & 77 & 131 \\
\hline
\end{tabular}

The $\mathrm{H}_{2}$ content at the level of the upper shaft probe was higher during operation with oxygen enrichment compared to operation with air addition to the coal lance, as can be observed comparing test periods 1 with 2 and 5 with 6 , but the result could depend, at least in part, on the higher PCR during operation with oxygen enrichment.

In the investigated cases, a higher temperature level in the EBF can be expected during injection of the HV coal. The differences in $\mathrm{H}_{2}$ content in the ascending gas but likely also the higher temperature were the explanations for the higher reduction degree observed in samples taken out with the upper shaft probe during injection of the HV coal type, compared to during LV coal operation. The effect of temperature and reduction gas composition on the reduction agrees with the observations made by Towhidi. ${ }^{5,6)}$ At the level of the lower shaft probe the $\mathrm{H}_{2}$ content was higher compared to the attained amounts at the level of the upper shaft probe. In pellets taken out with the lower shaft probe, significant differences in average reduction degree were not found and no correlation between pre-set process conditions and reduction degree could be observed. The results indicated that the test conditions in terms of the reduction potential of the gas, temperature profile and time for all cases resulted in a thermal reserve zone that was long enough for sufficient indirect reduction of pellets under all the investigated process conditions. Due to the central coke charging, the reduction potential of the gas was higher in the centre of the furnace.

\subsubsection{Laboratory Simulated PCR}

Generally, experiments simulating higher PCR resulted in a higher pellet reduction degree at an equal reduction time. However, the initial reduction temperature and heating rate were of importance for the reduction degrees attained. A higher start reduction temperature resulted in a faster initial reduction. On the other hand, a faster heating rate compensated for a lower start temperature and lower simulated PCR. Despite differences in simulated PCR, an approximately equal reduction degree was attained for the experiment simulating low PCR and fast heating rate and the experiment simulating high PCR and slow heating rate at a reduction time exceeding $35 \mathrm{~min}$. If these results are applied to the actual BF process, it can be concluded that the increase in reduction potential of the gas and a higher temperature level compensate for the possible loss in reduction time when the PCR is increased.

\subsection{Texture}

\subsection{1. $\mathrm{EBF}$}

$\mathrm{Fe}_{\text {met }}$ areas were observed in pellets taken out with the upper shaft probe for all pre-set process conditions during injection of the HV coal. During injection of the LV coal type, corresponding $\mathrm{Fe}_{\text {met }}$ areas were not observed. During injection of the LV coal type a few areas of hematite were observed in the pellet core, which was not the case in pellets taken out during injection of the HV coal type. The differences in temperature and reduction potential of the gas at high PCR explain the differences in pellet textures under injection of the different coal types. It was likely that the coal type had a corresponding effect on the ascending gas composition at low PCR, but since a period of lower heat level in the EBF occurred during low PCR operation and injection of the HV coal type, the relation could not be proven for the tests performed.

$\mathrm{Fe}_{\text {met }}$ dominated in pellets taken out with the lower shaft probe. The pores of the $\mathrm{Fe}_{\text {met }}$ textures were larger after reduction during injection of the HV coal. In the core of pellets taken out during test period 5, high PCR, HV coal, and oxy coal operation, the largest areas of $\mathrm{Fe}_{\text {met }}$ were found. The marked off areas of $\mathrm{Fe}_{\text {met }}$ were observed to be more compact after operation with the HV coal type compared to the LV coal. The increase in pore size after HV coal operation was partly a consequence of the higher temperature level and agrees with the observations made by Wright ${ }^{10)}$ under isothermal conditions. According to Turkdogan ${ }^{8)}$ the initial reduction temperature is of major importance for the pore structure of the reduced iron and a structure that is formed at a low reduction temperature does not readily coarsen at subsequent temperature rise, which agrees with the results attained in pellets taken out with the lower shaft probe. A straggling $\mathrm{Fe}_{\text {met }}$ texture was, especially in the pellet periphery, identified after operation with the LV coal type. Previous investigation showed that the generation of fines increases during injection of the HV coal type. ${ }^{1)}$ During abrasion, the edges of the straggling $\mathrm{Fe}_{\text {met }}$ areas get stuck in each other, while a smooth $\mathrm{Fe}_{\text {met }}$ surface area does not exhibit this property. Since the $\mathrm{Fe}_{\text {met }}$ areas with smooth surfaces dominated during $\mathrm{HV}$ coal injection, the $\mathrm{Fe}_{\text {met }}$ texture is assumed to be one explanation for the increase in fines generation compared to LV coal operation. Examples of typical straggling and smooth $\mathrm{Fe}_{\text {met }}$ textures are presented in Fig. 17. The test conditions in the EBF, in terms of reduction potential of the gas and temperature profile, do not result in formation of distinct product layers in the reduced pellets. No micro-porosity was observed in the 


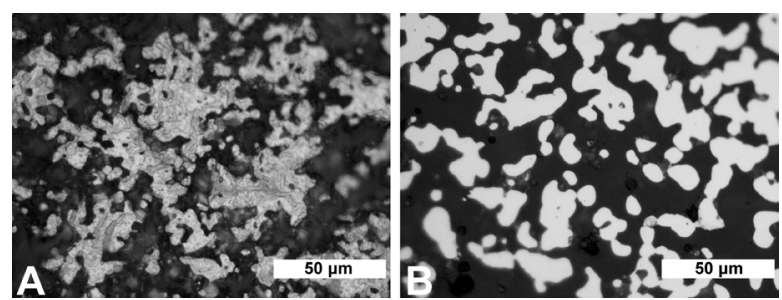

Fig. 17. Typical examples of a straggling $\mathrm{Fe}_{\text {met }}$ texture (A) and a smooth $\mathrm{Fe}_{\text {met }}$ texture (B).

$\mathrm{Fe}_{\text {met }}$ areas in pellets taken out with the shaft probes.

In pellets taken out with the lower shaft probe during injection of the HV coal the slag areas and the surface cover were observed to be softened. Corresponding observations were not made in samples from injection with the LV coal. No correlation between the pre-set process conditions and elements observed in the slag areas and surface cover could be observed. The formation of softened slag areas indicates exposure to a higher temperature level and it could therefore be concluded that injection of the HV coal type, in the investigated cases, resulted in an increase in the temperature level in the EBF at the position of the lower shaft probe.

Differences in the location of areas with an increased $\mathrm{K}$ content were observed between pellets taken out with the lower shaft probe. During injection of the LV coal type, $\mathrm{K}$ was found next to $\mathrm{Fe}_{\text {met }}$, while $\mathrm{Fe}_{\text {met }}$ surrounds $\mathrm{K}$ during injection of the HV coal type. Since the solubility of $\mathrm{K}$ in iron oxides has been reported to be low, it seems probable that $\mathrm{K}$ will condense on the iron oxide surfaces. ${ }^{13)}$ In a porous grain the $\mathrm{K}$ might reach the centre of the grain and in this way $\mathrm{K}$ could be surrounded by $\mathrm{Fe}_{\text {met }}$ when the iron oxide $/ \mathrm{Fe}_{\text {met }}$ becomes more compact as the pellets descend through the EBF. The texture of a wustite grain was more porous in comparison to a magnetite grain. Accordingly, the formation of $\mathrm{K}$ surrounded by $\mathrm{Fe}_{\text {met }}$ was reasonably facilitated if $\mathrm{K}$ condensated on wustite instead of magnetite. Chemical analysis of the pellets taken out with the shaft probes showed a higher $\mathrm{K}$ content in pellets taken out with the lower shaft probe compared to the upper shaft probe. It could be concluded that a major part of the K condensation had taken place at the position between the shaft probes. Since a higher reduction degree was attained in pellets taken out with the upper shaft probe during injection of the HV coal type and the grains were found to be more porous than during injection of the LV coal type, $\mathrm{K}$ would most probably condensate inside the porous grain texture and give rise to the texture with $\mathrm{K}$ surrounded by $\mathrm{Fe}_{\text {met }}$.

\subsubsection{Laboratory Reduction}

A simulated low PCR resulted in a grain texture in the pellet core that was not observed at simulated high PCR. In the pellet periphery, iron oxides were surrounded by $\mathrm{Fe}_{\text {met }}$ and the $\mathrm{Fe}_{\text {met }}$ texture was denser at low PCR. The pores in the pellet periphery were larger at high PCR. Tests IV and VI showed, despite similar reduction profiles above a reduction degree of $25 \%$, differences in pellet texture. The texture differences were most likely to occur in the beginning of the reduction. Differences in the pellet textures that were observed in samples after reduction to $1100^{\circ} \mathrm{C}$ were al- ready found at a reduction degree of $40 \%$. These observations supported the claim that the observed texture differences were introduced at the beginning of reduction. A higher start reduction temperature and a more rapid temperature increase in combination with an increase in the reduction potential of the reduction gas counteracted the formation of a grain texture in the pellet core. At the same time, a porous $\mathrm{Fe}_{\text {met }}$ texture was formed in the pellet periphery. The results from the present investigations agree with observations made by Turkdogan, ${ }^{8)}$ which state that the initial reduction temperature was of major importance for the pore structure of the reduced iron.

\subsection{Carburization of Pellets}

$\mathrm{Fe}_{3} \mathrm{C}$ was observed in fractions formed during tumbling of pellets taken out with the lower shaft probe in test periods 2-6. Chemical analysis showed an increase in C content in corresponding samples during injection of the $\mathrm{HV}$ coal type. It is assumed that the increase in $\mathrm{C}$ content is due to an increase in the amount of $\mathrm{Fe}_{3} \mathrm{C}$ during injection of the HV coal type.

Carburization of reduced iron or wustite forming iron carbide, $\mathrm{Fe}_{3} \mathrm{C}$, can take place according to ${ }^{17)}$

$$
3 \mathrm{Fe}+\mathrm{C} \rightarrow \mathrm{Fe}_{3} \mathrm{C} \text {. }
$$

$$
3 \mathrm{Fe}+2 \mathrm{CO} \rightarrow \mathrm{Fe}_{3} \mathrm{C}+\mathrm{CO}_{2}
$$

$$
3 \mathrm{FeO}+5 \mathrm{CO} \rightarrow \mathrm{Fe}_{3} \mathrm{C}+4 \mathrm{CO}_{2}
$$

Larger pores facilitated the diffusion of $\mathrm{CO}$ in the pellets and $\mathrm{Fe}_{3} \mathrm{C}$ formed according to Eq. (2) was facilitated by the increased contact area between $\mathrm{Fe}_{\text {met }}$ and $\mathrm{CO}$. Larger pores, possibly not only formed as a consequence of increased temperature but also as a result of the $\mathrm{Fe}_{3} \mathrm{C}$ content, were observed in the pellets taken out during injection of the $\mathrm{HV}$ coal type. The differences in pellet reduction degree obtained with the different coal types receded through the shaft but most likely remained below the position of the upper shaft probe. $\mathrm{Fe}_{3} \mathrm{C}$ was formed in the shaft between the positions of the shaft probes. A higher amount of $\mathrm{H}_{2}$ in the ascending gas facilitated the iron oxide reduction by $\mathrm{H}_{2}$ and as a consequence the $\mathrm{CO}$ concentration available for carburization increased.

Reaction of $\mathrm{Fe}_{3} \mathrm{C}$ with wustite, Eq. (4), at temperatures above $900^{\circ} \mathrm{C} \mathrm{Fe}_{3} \mathrm{C}^{18)}$

$$
2 \mathrm{FeO}+\mathrm{Fe}_{3} \mathrm{C} \leftrightarrow 5 \mathrm{Fe}+\mathrm{CO}_{2}
$$

was more likely to occur during injection of the LV coal type, since the pellet reduction degree was lower. Therefore, a lower carbon content should be expected when using the LV coal which is in agreement with the present results.

\subsection{Sources of Error in the Texture Observations}

According to the literature, a random distribution of pores has been observed in magnetite formed during reduction of hematite pellets, but magnetite without internal porosity was also observed. ${ }^{19)}$ The magnetite textures were obtained at different temperatures and at different reduction gas compositions. In the present investigations it was assumed that no internal porosity existed in the magnetite and that the areas of similar colour in the microscope, in which 
internal porosity was observed, consisted of wustite. There is a possibility that magnetite and wustite were not kept separate at all times. It cannot be concluded for certain that carbon deposition did not occur during the laboratory reduction tests performed; if so was the case, a higher reduction degree compared to the ones presented might have been reached.

\subsection{Concluding Discussion}

The results from the EBF tests indicated that the test conditions in terms of the reduction potential of the gas, temperature profile and time for all cases resulted in an extension of the thermal reserve zone that was sufficient for reduction of pellets under all the investigated process conditions. The different $\mathrm{Fe}_{\text {met }}$ textures observed in pellets taken out with the lower shaft probe indicated differences in reduction conditions at positions above the lower shaft probe in the EBF. The initial reduction conditions, in terms of temperature and gas composition, were in the performed investigations conclusive for the pellet texture formed.

\section{Conclusions}

The reduction behaviour of olivine pellets and textures formed during operation in the EBF were investigated. In the investigations performed, an LV and an HV coal type were injected at different PCR while two types of oxygen supply methods were employed. The choice of injection coal type was conclusive for the $\mathrm{Fe}_{\text {met }}$ texture formed during reduction, extent of $\mathrm{Fe}_{\text {met }}$ carburization and $\mathrm{K}$ distribution in the pellet. An HV injection coal resulted in a pellet texture with larger pores and smoother $\mathrm{Fe}_{\text {met }}$ areas in the pellet periphery, increased $\mathrm{Fe}_{3} \mathrm{C}$ formation and areas of $\mathrm{K}$ surrounded by $\mathrm{Fe}_{\text {met }}$. The amount of $\mathrm{VM}$ in the coal type had a greater effect on the pellet reduction properties than the PCR and oxygen supply methods.

Based on the laboratory experiments simulating PCR it was concluded that the initial reduction conditions, in terms of temperature level and reduction gas composition, will determine the pellet texture up to a reduction degree of at least $60 \%$.

The tests carried out in the EBF showed that the tested pellets were well suited for blast furnace reduction at the studied PCR, with injection of LV and HV coal types and for the current methods of oxygen supply. During all the in- vestigated process conditions, sufficient pellet reduction degrees were attained in the lower part of the EBF shaft. According to the results from laboratory reduction tests simulating high and low PCR, the pellet samples showed sufficient reducibility at the investigated PCR levels.

\section{Acknowledgements}

We are grateful to the Swedish Energy Agency and the Swedish Foundation for Strategic Research for financial support. The members of the Swedish Steel Producers' Association JK21059 project and the Agricola Research Centre are acknowledged. Thanks to LKAB and SSAB for support and assistance in the work. A special thanks to LKAB for providing the opportunity to carry out tests in the EBF. Finally, we thank Mr. Johan Folkesson for designing the laboratory furnace control system at LTU.

\section{REFERENCES}

1) U. Leimalm, L. S. Ökvist, A. Brännmark and B. Björkman: Proc. of the Iron and Steel Technology Conf., Association for Iron \& Steel Technology, Warrendale, PA, (2006), 39.

2) S.-H. Yi, W.-W. Huh, C.-H. Rhee and B.-R. Cho: Scand. J. Metall., 28 (1999), 260.

3) A. Maki, A. Sakai, N. Takagaki, K. Mori, T. Ariyama, M. Sato and R. Murai: ISIJ Int., 36 (1996), 650.

4) K.-H. Peters, M. Peters, B. Korthas, K. Mülheims and K. Kreibich: Metall. Plant Technol. Int., 6 (1990), 32.

5) N. Towhidi: Arch. Eisenhüttenwes., 55 (1984), 91.

6) N. Towhidi: 3rd Int. Symp. on Beneficiation and Agglomeration Indian Institute of Metals, Orissa, (1991), 487.

7) D. H. St. John, S. P. Matthew and P. C. Hayes: Bull. Proc. Australas. Inst. Min. Metall., 290 (1985), 61.

8) E. T. Turkdogan: Metall. Trans. B, 9B (1978), 163.

9) R. G. Olsson and W. M. McKewan: Metall. Trans., 1 (1970), 1507.

10) J. K. Wright: Pellets and Granules Symp., Australas. Inst. of Min. and Metall., Newcastle, Australia, (1974), 121.

11) S. Geva, M. Farren, D. H. St. John and P. C. Hayes: Metall. Trans. B, 21B (1990), 743.

12) Q. Zhou and X. Bi: Scand. J. Metall., 16 (1987), 57.

13) S. Hayashi and Y. Iguchi: ISIJ Int., 29 (1989), 642.

14) E. Lectard, E. Hess and R. Lin: La Revue Metall., 101 (2004), 31.

15) U. Leimalm, L. S. Ökvist and B. Björkman: Proc. of The 4th Int. Cong. on the Science and Technology of Ironmaking, ISIJ, Tokyo, (2006), 201.

16) LKAB 2004, The Products, (2004), 25.

17) A. A. El-Geassy and M. I. Nasr: ISIJ Int., 30 (1990), 417.

18) M. I. Nasr, A. A. Omar, M. M. Hessien and A. A. El-Geassy: ISIJ Int., 36 (1996), 164.

19) A. V. Bradshaw and A. G. Matyas: Metall. Trans. B, 7B (1976), 81. 